\title{
Suplemen Calcitriol Dosis Tinggi Mencegah Osteoporosis dan Memicu Urolitiasis pada Tikus Ovariektomi
}

\section{High Dose of Calcitriol Supplementation Prevent Osteoporosis and Trigger Urolithiasis in Ovariectomized Rats}

\author{
Hartiningsih*, Devita Anggraeni \\ Departemen Ilmu Bedah dan Radiologi, Fakultas Kedokteran Hewan, Universitas Gadjah Mada \\ *E-mail: hartiningsih56@yahoo.com
}

Naskah diterima: 26 Juni 2019, direvisi: 11 Februari 2021, disetujui: 24 Juni 2021

\begin{abstract}
Calcitriol supplementation in ovariectomized rats for 8 weeks reduce osteoporosis risk and safe for kidney depend a proper dose. The objective of the research was to study the efectivity of high dose calcitriol for osteoporosis prevention and safe for kidney in ovariectomized Wistar rats. Fifteen female Wistar rats at 8 weeks of age were randomly divided into three groups of five which were sham operated rats (KN), ovariectomized rats (KOV), and ovariectomized rats + calcitriol supplementation $200 \mathrm{ng} /$ day $\left(\mathrm{OVD}_{200}\right)$. After 8 weeks of treatment, blood samples were taken from plexus orbitalis medialis for estrogen analysis. All rats were then euthanized, left tibia and left kidney were taken for histopathological examination using hematoxylin and eosin stain. Immunohistochemistry using Anti-Tartrate Resistant Acid Phosphatase 5b (TRAP5b) monoclonal antibody was also done for left tibia by streptavidin-biotin. The results showed that estradiol level of KOV was significantly decreased compared with $\mathrm{KN}(\mathrm{P}<0.05)$, meanwhile, estradiol levels of $\mathrm{OVD}_{200}$ were not significantly different compared with KOV. Histopathologic figure of kidney in KOV was not different compared with KN. Glomerulus was surrounded by Bowman's capsule, proximal and distal convoluted tubulus were lined with typical cuboidal epithelium. Immunohistochemistry result of proximal tibial epiphysis in KOV were shown more tartrate resistant alkaline phosphatase $5 b$ (TRAP5b) expression in trabecular bone, which was located in bone marrow space, and trabecular speculum surface as well. Meanwhile, proximal tibia epiphysis in $\mathrm{OVD}_{200}$ had less tartrate resistant alkaline phosphatase $5 b$ (TRAP5b) expression compared with KOV. Histopathologic figure of proximal tibia epiphysis in group $\mathrm{OVD}_{200}$ was shown more trabecular bone speculum and less adipocyte in the bone marrow compared with KOV. Histopathologic figure of kidney in $\mathrm{OVD}_{200}$ was showed glomerular hypertrophy and atrophy, as well as protein deposits in proximal convoluted tubules epithelium. In conclusion, calcitriol supplementation 200ng/day in ovariectomized rats for 8 weeks prevented osteoporosis risk but trigger urolithiasis.
\end{abstract}

Keywords: Calcitriol; osteoporosis; ovariectomized rats; urolithiasis

\begin{abstract}
Abstrak
Suplemen calcitriol efektiv menurunkan risiko osteoporosis dan aman bagi ginjal tikus ovariektomi tergantung dosis. Penelitian ini dilakukan untuk mengkaji apakah suplementasi calcitriol dosis tinggi selama delapan minggu efektif mecegah osteoporosis dan aman bagi ginjal tikus ovariektomi. Limabelas tikus Wistar betina umur delapan minggu, dibagi tiga kelompok (kontrol normal KN, kontrol ovariektomi KOV, dan ovariektomi + calcitriol $\mathrm{OVD}_{200}$ ), masing-masing 5 tikus. Setelah delapan minggu perlakuan, dilakukan pengambilan darah melalui pleksus retroorbilatis untuk pemeriksaan estrogen, selanjutnya semua tikus dietanasi menggunakan campuran ketamin $10 \%$ dengan xylaxine 2\%. Tibia kiri diambil untuk pemeriksaan histopatologis dengan pengecatan hematoksilin dan eosin, dan immunohistokimia menggunakan antibodi
\end{abstract}


monoklonal Anti-Tartrate Resistant Acid Phosphatase $5 b$ (TRAP5b) dan dideteksi dengan streptavidin-biotin, ginjal kiri juga diambil untuk pemeriksaan histopatologis. Hasil analisis menunjukkan tikus KOV mempunyai konsentrasi estradiol lebih rendah dibanding tikus $\mathrm{KN}$, sedangkan tikus $\mathrm{OVD}_{200}$ mempunyai konsentrasi estradiol tidak berbeda signifikan dibanding tikus KOV. Pemeriksaan immunohistokimia epifisis tulang tibia proksimalis tikus $\mathrm{OVD}_{200}$ terlihat lebih sedikit ekspresi TRAP5b pada tulang trabekula dalam rongga sumsum tulang dan permukaan spikulum trabekula dibanding tikus KOV. Pada pemeriksaan histopatologis terlihat lebih sedikit adiposit dalam rongga sumsum tulang dan lebih banyak spikulum trabekula dibanding tikus KOV. Histopatologis ginjal tikus KOV tidak berbeda dengan tikus KN, sedangkan pada tikus $\mathrm{OVD}_{200}$ terlihat glomerulus hipertrofi dan atrofi, endapan protein dalam ruang Bowman's dan tubulus proksimalis. Dari hasil penelitian disimpulkan bahwa suplementasi calcitriol 200ng/hari selama delapan minggu pada tikus ovariektomi dapat mencegah risiko osteoporosis namun memicu urolitiasis.

Kata kunci: Calcitriol; osteoporosis; tikus ovariektomi; urolitiasis

\section{Pendahuluan}

Ovariektomi pada tikus menurunkan konsentrasi estradiol (Hartiningsih dan Anggraeni, 2018; Li et al., 2013; Pan et al., 2010), meningkatkan resorpsi tulang, menurunkan pembentukan tulang (Hartiningsih dan Anggraeni, 2016; Hartiningsih dan Anggraeni, 2015; Riggs et al., 2002; Khosla et al., 2002), dan menyebabkan osteoporosis atau rapuh tulang (Hartiningsih dan Anggraeni, 2018; Hartiningsih dan Anggraeni, 2017; Hartiningsih dan Anggraeni, 2016; Hartiningsih dan Anggraeni, 2015; Shiud et al., 2011). Osteoporosis atau rapuh tulang menyebabkan tulang cenderung mudah fraktur meskipun hanya terkena trauma ringan (Potu et al., 2009). Terapi sulih hormon menggunakan hormon estrogen dapat meningkatkan pembentukan tulang dan menurunkan resorpsi tulang (Hartiningsih dan Anggraeni, 2018; Hartiningsih dan Anggraeni, 2017; Shuid et al., 2011), dan menurunkan risiko fraktur tulang (Bowring dan Francis, 2011; Ribot dan Tremollieres, 2006), namun meningkatkan risiko kanker ovarium, endometrium dan kelenjar mammae (Zarate el al., 2014; Hartiningsih and Anggraeni, 2015; Messina dan Wood, 2008; Udell et al., 2006; Raisz, 2005).

Vitamin $\mathrm{D}_{3}$ dapat menurunkan risiko kanker endometrium (Mohr et al., 2007; Salazar-Martinez et al., 2005). Suplemen 1,25-dihidroksivitamin $\mathrm{D}_{3}$ meningkatkan 1,25-dihidroksivitamin $\mathrm{D}_{3}$ plasma (Vieth et al., 2000; Wood et al., 1998), mempromotori absorpsi $\mathrm{Ca}$ intestinal dan reabsorpsi $\mathrm{Ca}$ tubulus ginjal (van de Graaf et al., 2004; van Abel et al., 2003; Song et al., 2003; van Cromphaut et al., 2001; Hoenderop et al., 2001), memicu pembentukan tulang dan meningkatkan densitas tulang (Anderson et al., 2006; Hendy et al., 2006). Asupan vitamin D 175-200 ng/hari dapat menurunkan $26 \%$ risiko patah tulang femur (Bischoff-Ferrari et al., 2005). Kombinasi antara suplemen vitamin D $200 \mathrm{ng} / \mathrm{hari}$ dan 1000-1200 $\mathrm{mg} \mathrm{Ca} /$ hari juga dapat menurunkan risiko patah tulang pada perempuan pasca menopause (Rizzoli et al., 2008). Suplementasi calcitriol $8 \mathrm{ng} /$ tikus selama 6 minggu pada tikus ovariektomi yang diberi pakan dengan rasio $\mathrm{Ca}: \mathrm{P}$ normal menurunkan estradiol dan menyebabkan osteoporosis namun tidak merubah struktur ginjal (Hartiningsih et al., 2012). Hal yang sama terjadi pada tikus ovariektomi yang diberi suplementasi calcitriol $20 \mathrm{ng} /$ tikus selama 8 minggu (Hartiningsih dan Anggraeni, 2013). Apakah suplementasi calcitriol $200 \mathrm{ng} /$ tikus selama delapan minggu efektif menurunkan osteoporosis dan aman bagi ginjal tikus ovariektomi belum pernah dilaporkan. Untuk mengukur efektifitas calcitriol dalam mencegah osteoporosis dilakukan pemeriksaan estradiol, parameter adiposit dan TRAP5b sebagai petanda aktivitas osteoklas meresorpsi tulang, dan spikulum trabekula sebagai petanda meningkatnya aktivitas osteoblas membentuk tulang. Untuk mengukur suplementasi calcitriol aman bagi ginjal dilakukan pemeriksaan histopatologis ginjal. Hasil penelitian ini diharapkan dapat memberi informasi tentang manfaat suplementasi calcitriol pada tulang dan aman bagi ginjal jika dikonsumsi individu pasca menopause. 


\section{Materi dan Metode}

Dalam penelitian ini digunakan 15 tikus Wistar betina umur 8 minggu, diberi pakan standar yang mempunyai kandungan protein $20 \%$, Ca 0,6\%, P 0,4\% dengan komposisi pakan (g/100 g pakan) terdiri dari 78\% jagung, 20\% ikan teri tawar, $0,3 \% \mathrm{CaCO}_{3}, 0,7 \%$ molase, dan $1,0 \%$ vitamin mineral.

Tikus ditempatkan dalam kandang individu berukuran panjang $24 \mathrm{~cm}$, lebar $13,5 \mathrm{~cm}$, tinggi $16,5 \mathrm{~cm}$, beralas anyaman kawat yang ditempatkan $4 \mathrm{~cm}$ dari dasar kandang, dengan suhu ruang berkisar $22-25^{\circ} \mathrm{C}$. Tikus diberi pakan standar dan air minum aquabidestilata secara ad libitum. Tikus dibagi 3 kelompok : kontrol normal (KN), kontrol ovariektomi (KOV), ovariektomi+ calcitriol 200 ngram/ hari/tikus secara oral $\left(\mathrm{OVD}_{200}\right)$, masingmasing 5 tikus. Seminggu pasca adaptasi pakan, dilakukan operasi ovariektomi bilateral (pengambilan ovarium kiri dan kanan) melalui sayatan caudal midline, sayatan pada kulit dibuat sepanjang $2 \mathrm{~cm}$ mulai dari umbilikus ke arah kaudal. Sebagai anestetikanya digunakan campuran ketamin $10 \%$ dosis $50 \mathrm{mg} / \mathrm{kg}$ (Pantex Holland) dan xylazine $2 \%$ dosis $5 \mathrm{mg} /$ $\mathrm{kg}$ (Pantex Holland) intramuskuler. Hal yang sama dilakukan pada tikus kontrol meskipun tidak dilakukan pengambilan ovarium (operasi semu). Satu minggu pasca operasi, semua tikus diberi perlakuan selama delapan minggu.

Pada akhir perlakuan, tikus dianestesi dengan campuran xylazine $2 \%$ dan ketamin $10 \%$, darah diambil melalui pleksus retroorbitalis untuk pemeriksaan estradiol, selanjutnya tikus dietanasi dengan campuran xylazine 2\% dan ketamin $10 \%$, tulang tibia kiri diambil dan difiksasi dalam formalin 10\% untuk pemeriksaan histopatologis dan pemeriksaan immunohistokimia TRAP5b, menggunakan monoklonal antibodi anti TRAP5b (BioLegend, SanDiego), dan dideteksi menggunakan streptavidin-biotin (Histostain-SP Kits, Invitrogen Ltd, UK). Ginjal kiri diambil dan difiksasi dalam formalin $10 \%$ untuk pemeriksaan histopatologis. Estradiol diperiksa dengan ELISA (Omega Laboratorium).

Data estradiol serum yang diperoleh dianalisis dengan sidik ragam pola searah yang dilanjutkan dengan uji Duncan's. Histopatologis tulang dan ginjal, dan pemeriksaan immunohistokimia TRAP5b pada tulang yang diperoleh dianalisis secara diskriptif.

\section{Hasil dan Pembahasan}

Ovariektomi menyebabkan konsentrasi estradiol tikus KOV 10,45 $\pm 1,29 \mathrm{pg} / \mathrm{ml}$ cenderung lebih rendah meskipun tidak berbeda signifikan dengan tikus KN 12,10 $\pm 1,09 \mathrm{pg} / \mathrm{ml}$ (Tabel 1). Li et al., (2013) dan Pan et al., (2010) melaporkan bahwa ovariektomi pada tikus menurunkan konsentrasi estradiol.

Tabel 1. Kadar estrogen (pg/ml) tikus kontrol normal (KN), kontrol ovariektomi (KOV), dan ovariektomi + calcitriol 200 ngram/hari/tikus secara oral $\left(\mathrm{OVD}_{200}\right)$

\begin{tabular}{cc}
\hline \hline Kelompok & Kadar estradio $(\mathrm{pg} / \mathrm{ml})$ \\
\hline \hline KN & $12,10 \pm 1,09$ \\
KOV & $10,45 \pm 1,29$ \\
OVD $_{200}$ & $10,97 \pm 1,05$ \\
\hline \hline
\end{tabular}

Histopatologis epifisis tulang tibia proksimalis tikus KOV (Gambar 1:B1) terlihat dominasi jaringan adiposit dalam rongga sumsum tulang dan lebih sedikit spikulum trabekula dibanding tikus KN (Gambar 1:A1). Gambaran immunohistokimia epifisis tulang tibia proksimalis tikus KOV (Gambar 1:B2 dan 1:B3) terlihat lebih banyak ekspresi TRAP5b pada tulang trabekula antar rongga sumsum tulang dan pada permukaan spikulum trabekula dibanding tikus KN (Gambar 1:A2 dan A3). Dominasi jaringan adiposit dalam rongga sumsum tulang epifisis tulang tibia proksimalis tikus KOV memberi gambaran meningkatnya aktivitas osteoklas meresorpsitulangyang diduga terkait dengan turunnya estrogen. Menurut Cooke dan Naaz (2004), dan Riggs et al., (2002) estrogen berperanan penting dalam mengendalikan osteoblas dan adiposit. Dilaporkan Verma et al., (2002), Justesen et al., (2001) dan Rodriguez et al., (1999) bahwa turunnya konsentrasi estrogen mengganggu proliferasi dan aktivitas estogenik dalam sumsum tulang dan menyebabkan lebih tingginya konversi sel stroma menjadi adiposit dibanding menjadi osteoblas. Menurut Weisberg et al., (2003) adiposit dalam rongga sumsum tulang tidak hanya menekan pembentukan 
tulang dengan menghambat osteoblastogenesis tetapi juga meningkatkan resorpsi tulang. Dilaporkan Mirkin dan Pickar (2013) bahwa rendahnya estrogen menjadi inisiator potensial osteoklas untuk meningkatkan resorpsi tulang. Lebih banyaknya ekspresi TRAP5b tikus KOV juga memberi gambaran bahwa ovariektomi menyebabkan lebih tingginya aktivitas osteoklas meresorpsi tulang dibanding tikus KN. Penggunaan TRAP5b sebagai petanda aktivitas resorpsi tulang oleh osteoklas adalah sesuai laporan Halleen dan Ranta (2001) bahwa sejak terjadi proses diferensiasi, prekursor osteoklas secara progresif mengekspresikan TRAP5b. Beberapa peneliti melaporkan bahwa osteoklas selama meresorpsi tulang juga mensekresikan TRAP5b (Janckila et al., 2001; Halleen et al., 2000; Vaananen et al., 2000; Alatalo et al., 2000). Turunnya spikulum trabekula epifisis tulang tibia proksimalis pada tikus ovariektomi $\mathrm{KOV}$ juga sesuai yang dilaporkan Cigiela et al., (2012) bahwa ovariektomi menurunkan spikulum trabekula dan rongga sumsum tulang menjadi lebih luas. Penggunaan spikulum trabekula
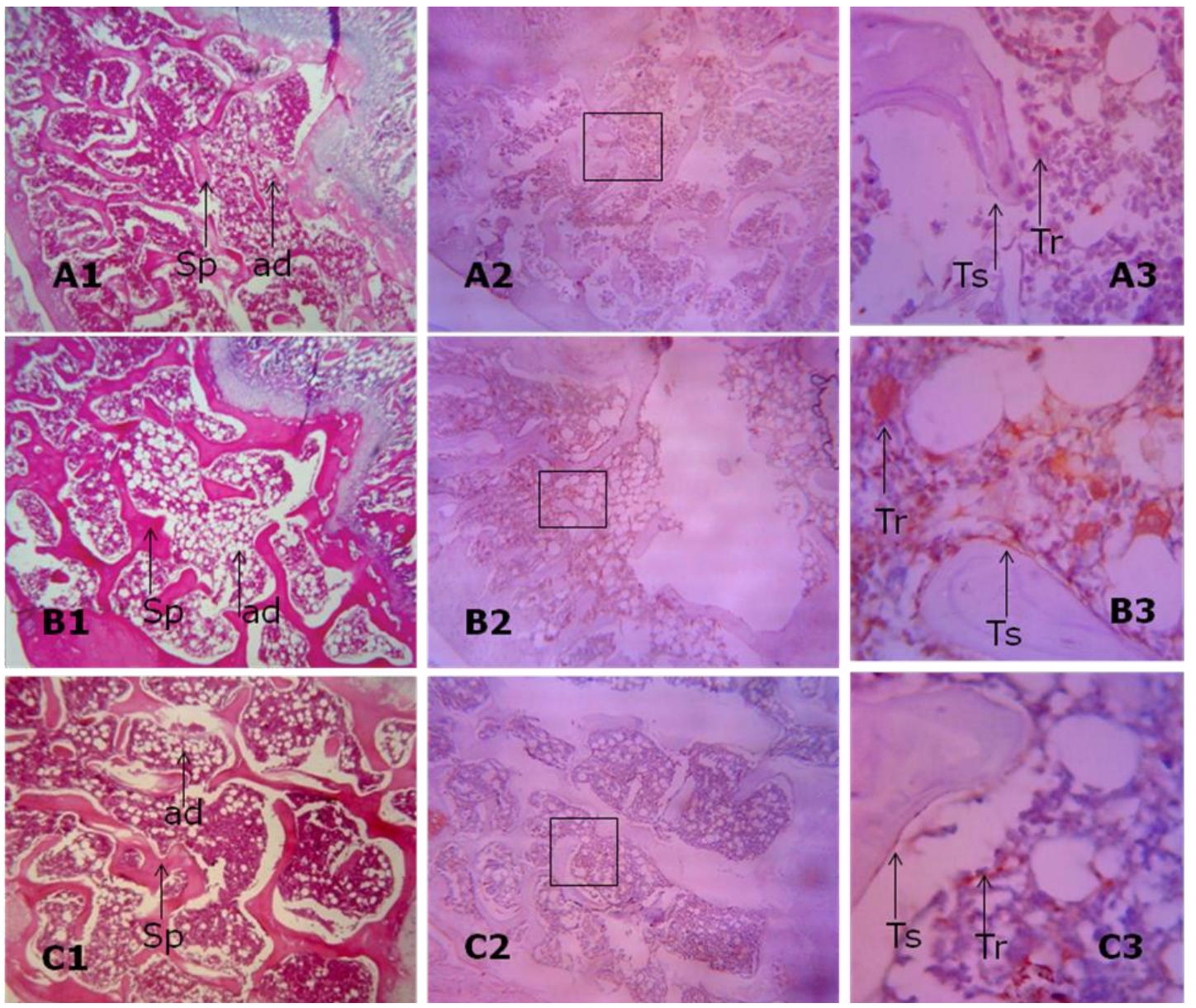

Gambar 1. Histopatologi epifisis tulang tibia proksimalis tikus KN (A1) terlihat rongga sumsum tulang normal dan spikulum trabekula normal (Sp), pada tikus KOV (B1) terlihat dominasi jaringan adiposit dalam rongga sumsum tulang $(\mathrm{ad})$ dan sedikit spikulum trabekula $(\mathrm{Sp})$, dan pada tikus $\mathrm{OVD}_{200}(\mathrm{C} 1)$ terlihat sedikit jaringan adiposit dalam rongga sumsum tulang (ad) dan lebih banyak spikulum trabekula (Sp) (H dan E, 100x.).

Bagian epifisis tulang tibia proksimalis tikus tikus KN yang diberi antibodi monoklonal anti tartrate resistant alkaline phosphatase $5 b$ (TRAP5b) (A2 dan A3) terlihat TRAP5b positif berwarna coklat pada trabekula tulang dalam rongga sumsum tulang (Tr) dan permukaan spikulum trabekula (Ts) (A2=Streptavidin-biotin, 100x.; A3= Streptavidin-biotin, 400x.). Pada tikus KOV diberi antibodi monoklonal anti tartrate resistant alkaline phosphatase $5 b$ (TRAP5b) (B2 dan B3) terlihat TRAP5b positif berwarna coklat pada trabekula tulang dalam rongga sumsum tulang (Tr) dan permukaan spikulum trabekula (Ts) (B2=Streptavidin-biotin, 100x.; B3= Streptavidin-biotin, 400x.). Pada tikus $\mathrm{OVD}_{200}$ yang diberi antibodi monoklonal anti tartrate resistant alkaline phosphatase $5 b$ (TRAP5b) (C2 dan C3) terlihat TRAP5b positif berwarna coklat pada trabekula tulang dalam rongga sumsum tulang (Tr) dan pada permukaan spikulun trabekula (Ts) $(\mathrm{E} 2=$ Streptavidin-biotin, 100x.; E3= Streptavidinbiotin, 400x.). 
sebagai petanda aktivitas osteoblas membentuk tulang adalah sesuai laporan Shiraishi et al. (2000) bahwa rekruitmen, diferensiasi osteoblas dan pembentukan tulang oleh osteoblas ditandai dengan banyak dan tebalnya spikulum trabekula. Menurut beberapa peneliti tidak seimbangnya antara resorpsi tulang dengan pembentukan tulang (Karsdal et al., 2007; Seeman et al., 2006; Martin and Sims, 2005; Teitelbaum and Ross, 2003; Goltzman, 2002), laju resorpsi tulang lebih tinggi dari pada pembentukan tulang menyebabkan osteoporosis (Palmer, 1993). Dalam penelitian ini, meningkatnya resorpsi tulang dan menurunnya pembentukan tulang pada tikus ovariektomi KOV memberi gambaran terjadi osteoporosis.

Suplementasi calcitriol menyebabkan tikus $\mathrm{OVD}_{200}$ mempunyai konsentrasi estradiol $10,97 \pm 1,05 \mathrm{pg} / \mathrm{ml}$ tidak berbeda signifikan dengan tikus KOV (Tabel 1). Pada pemeriksaan immunohistokimia epifisis tulang tibia proksimalis tikus ovariektomi $\mathrm{OVD}_{200}$ terlihat lebih sedikit ekspresi TRAP5b pada tulang trabekula antar rongga sumsum tulang dan pada permukaan spikulum trabekula (Gambar 1:C2 dan Gambar 1:C3). Pada pemeriksaan histopatologis (Gambar 1:C1) terlihat lebih sedikit jaringan adiposit dalam rongga sumsum tulang dan lebih banyak spikulum trabekula dibanding tikus KOV. Zhou et al., (2006), Kong dan Li (2006), Sun dan Zemel (2004) melaporkan bahwa 1,25-dihidroksivitamin $\mathrm{D}_{3}$ menginduksi apoptosis adipogenesis dan menghambat adipogenesis dalam sel. Menurut Weisberg et al., (2003) adiposit dalam rongga sumsum tulang meningkatkan resorpsi tulang. Lebih sedikitnya jaringan adiposit dan ekspresi TRAP5b tikus OVD $_{200}$ dibanding tikus KOV memberi gambaran bahwa suplementasi calcitriol pada tikus $\mathrm{OVD}_{200}$ menyebabkan lebih rendahnya aktivitas osteoklas meresorpsi tulang dibanding tikus KOV.Lebih banyaknya spikulum trabekula tikus OVD $_{200}$ dibanding tikus KOV memberi gambaran meningkatnya pembentukan
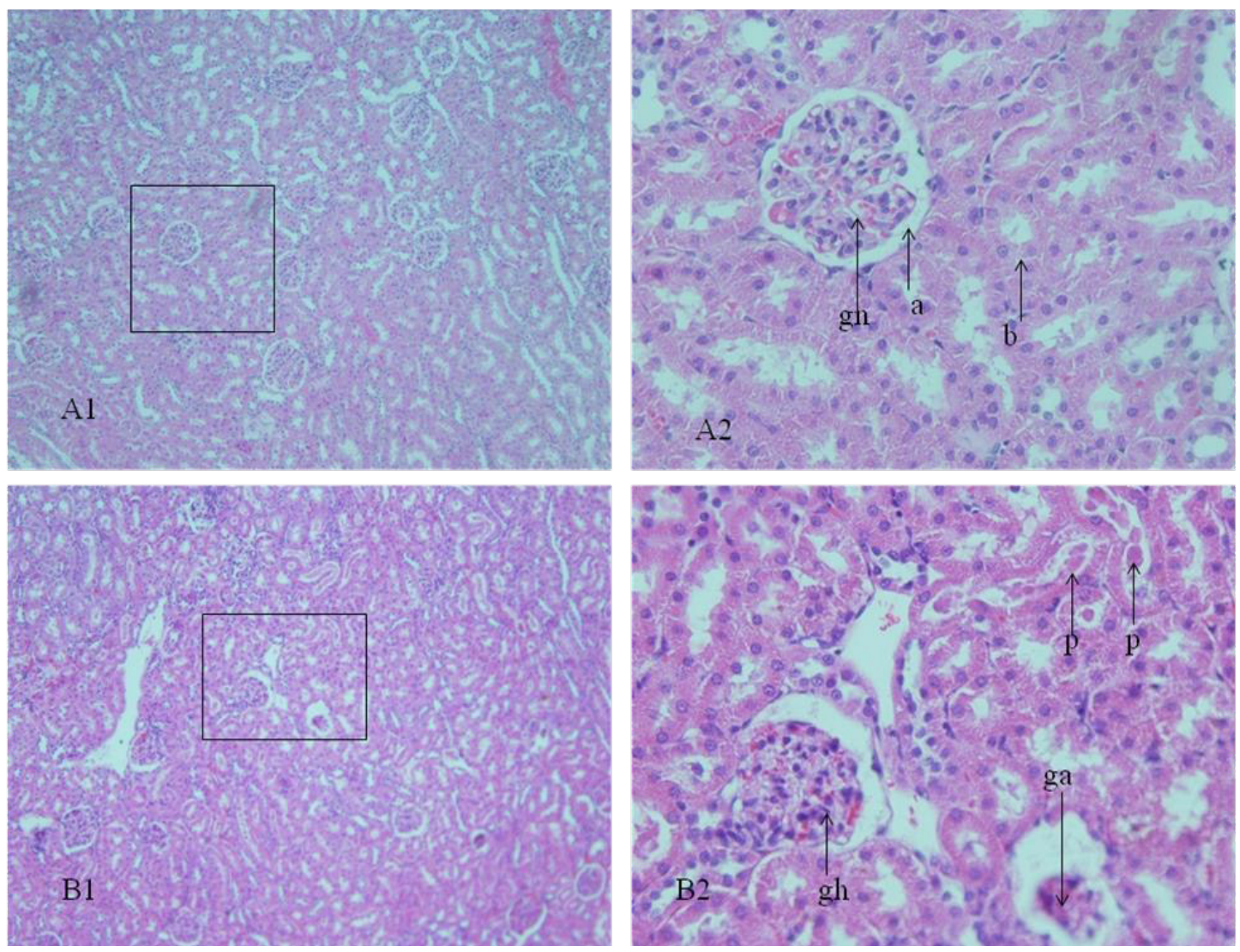

Gambar 2: A1 dan A2. Histopatologis ginjal tikus KN mempunyai struktur normal. Ruang Bowman's yang mengelilingi glomerulus terlihat jelas (a), sel epitel tubulus berbentuk kuboid (b), dan glomerulus normal (gn) (Hematoksilin dan eosin, 100x. dan 400x.).

$\mathrm{B} 1$ dan $\mathrm{B} 2$. Histopatologis ginjal tikus $\mathrm{OVD}_{200}$ terlihat endapan protein dalam lumen tubulus (p), glomerulus atrofi (ga) dan hipertrofi (gh) (Hematoksilin dan eosin, 100x. dan 400x.). 
tulang. Zhou et al., (2006) melaporkan bahwa 1,25-dihidroksivitamin $\mathrm{D}_{3}$ bekerja langsung pada osteoblas untuk meningkatkan pembentukan tulang. Dalam penelitian ini, tidak berbedanya konsentrasi estradiol tikus $\mathrm{OVD}_{200}$ dengan tikus KOV memberi gambaran bahwa suplementasi calcitriol 200ng/tikus pada tikus ovariektomi menurunkan resorpsi tulang dan meningkatkan pembentukan tulang.

Histopatologis ginjal tikus KOV (Gambar tidak ditampilkan) tidak ditemukan perubahan dan terlihat tidak berbeda dengan tikus KN (Gambar 2:A1 dan Gambar 2:A2), ruang Bowman's yang mengelilingi glomerulus terlihat jelas, kapsul Bowman's mempunyai epitel bentuk pipih, dan sel epitel tubulus proksimalis berbentuk kuboid tinggi dengan lumen lebih sempit, sel epitel tubulus distalis berbentuk kuboid pendek dengan lumen lebih luas sesuai yang digambarkan Teoh et al., (2010) dan Brzoska et al., (2003). Histopatologis ginjal tikus $\mathrm{OVD}_{200}$ (Gambar 2:B1 dan Gambar 2:B2) terlihat glomerulus hipertrofi dan atrofi, dan ditemukan endapan protein dalam ruang Bowman's dan tubulus proksimalis. Perubahan struktur ginjal tikus $\mathrm{OVD}_{200}$ diduga terkait dengan tingginya ekskresi Ca urin. Dalam penelitian ini tidak dilakukan pemeriksaan kalsium urin. Penelitian sebelumnya yang dilakukan Hartiningsih dan Anggraeni (2013) menunjukkan bahwa suplementasi calcitriol 20 ng pada tikus ovariektomi menyebabkan ekskresi $\mathrm{Ca}$ urin cenderung lebih tinggi meskipun tidak berbeda dengan tikus ovariektomi. Yacobus et al., (1992) dan Selby et al., (1995) melaporkan bahwa suplementasi 1,25-dihidroksivitamin $\mathrm{D}_{3}$ dosis tinggi menyebabkan hiperkalsemia dan hiperkalsiuria. Tingginya ekskresi Ca urin pada tikus yang diberi suplementasi calcitriol diduga akibat turunnya hormon paratiroid. Dilaporkan Seamans dan Casman (2009), Ramagnoli et al., (2008) dan Shiizaki et al., (2008) bahwa suplemen 1,25-dihidroksivitamin $\mathrm{D}_{3}$ menurunkan sekresi hormon paratiroid. Menurut Mihai dan Fardon (2000) hormon paratiroid bekerja pada ginjal untuk meningkatkan reabsorpsi $\mathrm{Ca}$, turunnya hormon paratiroid dengan demikian meningkatkan ekskresi $\mathrm{Ca}$ dalam urin. Dilaporkan Akil et al., (2006) bahwa tikus yang mengekskresikan $\mathrm{Ca}$ urin tinggi atau hiperkalsiuria menyebabkan iritasi pada sel epitel saluran perkencingan, menyebabkan kerusakan glomerulus dan tubulus proksimalis. Meningkatnya aktivitas filtrasi glomeruli terkait dengan tingginya ekskresi $\mathrm{Ca}$ dalam urin dapat menjadi pemicu hipertrofi glomerulus sebagaimana dilaporkan Silva (2008). Dilaporkan beberapa peneliti bahwa hipertrofi glomerulus memicu kerusakan glomerulus (Fries et al., 1989; Yoshida et al., 1989; Meyer dan Renner, 1988) dan menyebabkan nefrosis (Miller et al., 1990). Menurut Robertone (1998) kerusakan pada glomerulus dapat mempengaruhi aliran darah, menurunkan aliran darah dan menurunkan pengiriman oksigen. Dalam penelitian ini, endapan protein yang terlihat di dalam ruang Bowman's dan tubulus proksimalis pada tikus $\mathrm{OVD}_{200}$ adalah sesuai laporan Miller et al., (1990) bahwa dalam kondisi glomerulus hipertrofi, sel epitel yang rusak tidak dapat mempertahankan perlekatannya pada dinding kapiler, akibat lepasnya sel epitel dari dinding kapiler perifer menyebabkan lolosnya protein melalui dinding kapiler yang gundul. Bartges (2011), Brown dan Purich (1992) melaporkan bahwa supersaturasi urin oleh kristal kalkulogenik dan keberadaan matriks protein dapat menjadi faktor inisiasi terbentuknya inti urolit.

\section{Kesimpulan}

Dari hasil penelitian dapat disimpulkan bahwa suplemen calcitriol 200 ng/hari/tikus secara oral selama delapan minggu pada tikus ovariektomi dapat mencegah osteoporosis, namun memicu urolitiasis.

\section{Ucapan Terima Kasih}

Ucapan terima kasih disampaikan kepada Pendidikan Profesi Dokter Hewan Fakultas Kedokteran Hewan Universitas Gadjah Mada yang telah memberi dana penelitian.

\section{Daftar Pustaka}

Akil, I., Kavukcu, S., Inan, S., Yilmaz, O., Atilla, P., Islekel, H., Nese, N. and Muftuoglu, S. (2006) Evaluation of histologic changes in the urinary tract of hypercalciuric rats. Pediatr Nephrol 21: 1681-1689.

Alatalo, S.L., Halleen ,J.M., Hentunen, T.A., Monkkonen, J,. Vaananen, H.K. (2000) Rapid screening method for osteoclast 
differentiation in vitro that measures tartrate-resistant acid phosphatase 5b activity secreted into the culture medium. Clin Chem 46: 1751-4.

Anderson, G.L., Chlebowski, R.T., Rossouw, J.E. (2006) Prior hormone therapy and breast cancer risk in the women's health initiative randomized trial of estrogen plus progestin. Maturutas, 55: 103-115.

Bartges, J.W. (2011) Urinary saturation testing In: Bartges, J., Polzin, D.J., eds. Nephrology and urology of small animals. Ames: Wiley-Blackwell pp 75-85.

Bischoff-Ferrari, H.A., Willett, W.C., Wong, J.B., Giovannucci, E., Dietrich, T., DawsonHughes, B. (2005) Fracture prevention with vitamin D supplementation: a metaanalysis of randomized controlled trials. J.A.M.A., 293: 2257-2264.

Bowring, C.E. and Francis, R.M. (2011) National osteoporosis society's position statement on hormone replacement therapy in the prevention and treatment of osteoporosis. Menopause Int. 17: 63-65.

Brown, C., Purich, D. (1992) Physical-chemical prosecesses in kidney stone formation In : Coe F, Favus M, esd. Disorder of bone and mineral metabolism. New York, Raven Press, pp 613-624.

Brzoska, M.M., Moniuszko-Jakoniuk, J., PilatMarcinkiewicz, B., Sawicki, B. (2003) Liver and kidney function and histology in rats exposed to cadmium and ethanol. Alcohol \& Alcoholism 38(1): 2-10.

Cigiela, U., Folwarczna, J., Pytlik, M., and Zgorka, G. (2012) Effect of extracts from Trifolium medium L and Trifolium pratense L. on development of estrogen deficiency-induced osteoporosis in rats. Hindawi Publishing Corporation. Based Complemantary and Alternative Medicine. Article ID 921684.

Cooke, P.S., Naaz, A. (2004) Role of estrogens in adipocyte development and function. Exp. Biol. Med. 229: 1127-1135.

Fries, J.W.U., Sandstrom, D.J., Meyer, T.W., Rennke, H.G. (1989) Glomeruler hypertrophy and epithelial cell injury modulated progressive glomerulosclerosis in the rats. Blab. Inves.t 60: 205-217.

Goltzman, D. (2002) Discoveries, drugs and skeletal disorders. Nat. Rev. drug Discov. 1: 784-796.

Halleen, J.M., Ranta, R. (2001) Tartrate-resistant acid phosphatase as a serum marker of bone resorption. Am. Clin. Lab. 20: 2930 .

Halleen, J.M., Alatalo, SL, Suominen, H., Cheng, S., Janckila, A.J., Vaananen, H.K. (2000) Tartrate-resistant acid phosphatase 5b: a novel serum marker of bone resorption. J. Bone Miner. Res. 15: 1337-1345.

Hartiningsih, Nitisuwirjo, S., Wuryastuty, H. (2013) Respon tulang, ginjal dan kelenjar paratitoid tikus wistar yang mengkonsumsi pakan mengandung fosfor tinggi bervariasi. Jurnal Sain Veteriner. 31(1): 110-120.

Hartiningsih, Anggraeni, D., Widiyono, I., Wuryastuty, H. (2015) Respon tulang femur tikus ovariohisterektomi yang mengkonsumsi kasein dan disuplementasi calcitriol selama 30 minggu. Jurnal Veteriner. 16(1): $68-77$.

Hartiningsih dan Anggraeni, D. (2015) Suplementasi calcitriol menurunkan risiko osteoporosis tikus ovariektomi. Jurnal Sain Veteriner. 33(2): 143-148.

Hartiningsih and Anggraeni, D. (2015) The effectiveness of the combinations of calcitriol and ethynil ethyl estradiol to decrease osteoporosis and endometrial cancer risks in ovariectomized rats. Jurnal Kedokteran Hewan.11(2): 50-56.

Hartiningsih, Anggraeni, D. dan Sudarminto. (2016) Efektivitas diet teri tawar dan suplementasi kalsitriol untuk mencegah osteoporosis pada tikus ovariektomi. Jurnal Kedokteran Hewan. 10(1): 19-23.

Hartiningsih dan Anggraeni, D. ( 2016) Ekspresi Tartrate-resistant acid phosphatase $5 \mathrm{~b}$ pada epifisis tulang femur tikus ovariektomi yang mengkonsumsi kombinasi Calcitriol dan Raloxifene. Jurnal Veteriner. 17: 1-10. 
Hartiningsih, Puspitasari, A.D., Putri, N.D., Arifah, N., Pawestri, A., Anggraeni, D. (2017) Kombinasi calcitriol dan ethynil ethyl estradiol meningkatkan ekskresi kalsium urin dan risiko urolitiasis pada tikus ovariektomi. Jurnal Veteriner. 18(2): 239-246.

Hartiningsih and Anggraeni, D. (2017) The efectivitiveness of the combinations of calcitriol and ethynil ethyl estradiol to decrease osteoporosis and endometrial cancer risk in ovariectomized rats. Jurnal Kedokteran Hewan. 11(2): 50-56.

Hartiningsih dan Anggraeni, D. (2018) Respon tulang femur tikus osteoporosis yang mengkonsumsi calcitriol. Jurnal Sain Veteriner. 36(1): 1-10.

Hartiningsih, Anggraeni, D., Aji, D. (2012) Respon metafisis tulang femur distalis tikus ovariektomi yang mengkonsumsi kalsitriol. Jurnal Kedokteran Hewan 6: 92-98.

Hendy, G.N., Hruska, K.A., Mathew, S., Goltzman, D. (2006) New insights into mineral and skeletal regulation by active forms of vitamin D. Kidney Int. 69: 218223.

Hoenderop, J.G., Muller, D., Van Der Kemp, A,W., Hartog, A., Suzuki, M., Ishibashi, K., Imai, M., Sweep, F., Willems, P.H., Van Os, C.H., Bindels, R.J. (2001) Calcitriol controls the epithelial calcium channel in kidney. J. Am. Soc. Nephrol. 12: $1342-1349$.

Janckila, A.J., Takahasi, K., Sun, S.Z., Yam, L.T. (2001) Tartrate-resistant acid phosphatase isoform $5 \mathrm{~b}$ as serum marker for osteoclastic activity. Clin. Chem. 47: 74-80.

Justesen, J., Stenderus, K., Ebbesen, E.N., Moseklide, L., Steinche, T., Kassem, M. (2001) Adipocyte tissue volume in bone marrow is increased with aging and in patients with osteoporosis. Biogerontology. 2(3): 165-171.

Karsdal, MA., Martin, TJ., Bollerslev, J., Christiansen, C., Henriksen, K. (2007)
Are nonresorbing osteoclasts sources of bone anabolic activity ? J. Bone Miner. Res. 22: 487-494.

Khosla, S., Melton, L.J., and Riggs, B.L. (2002) Estrogen and the male skeleton. J. Clin. Endocrinol. Metab. 87: 1443-1450.

Kong, J., Li, Y.C. (2006) Molecular mechanism of 1,25-dihydroxyvitamin D3 inhibition of adipogenesis in 3T3-L1 cells. Am. J. Physiol Endocrinol Metab. 290: E916E924.

Li, F., Yang, Y., Guo, C., Zhang, C., Yang, Z., Li, P. (2013) Antiosteoporotic activity of echinacoside in ovariectomized rats. Phytomedicine. 15:20(6): 549-557.

Martin, T.J. and Sims, N.A. (2005) Osteoclast derived activity in the coupling of bone formation to resorption. Trend. Mol. Med., 11: 76-81.

Messina , M.J. and Wood, C.E. (2008) Soy isoflavones, estrogen therapy, and breast cancer risk, analysis and commentary. Nutr. J. 7:17.

Meyer, T.W., Rennke, H.G. (1988) Increased single nephrone protein excretion after renal ablation in ne.phritic rats. Am. J. Physio.l 255: F1243-1248.

Mihai, R., Faradon, J.R. (2000) Parathyroid disease and calcium metabolism. Britis Journal of Anaesthesia. 85: 29-43.

Miller, P.L., Scholey, J.W., Rennke, H.G., Meyer, T.W. (1990) Glomeruler hypertrophy aggravates epithelial cell injury in nephritic rats. J. Clin. Invest. 85: 1119-1126.

Mirkin, S. and Pickar, J.H. (2013) Management of osteoporosis and menopausal Symptoms: focus on bazedoxifenel conjugated estrogen combination. International Journal of Women health. 5: 465-475.

Mohr, S.B., Garland, C.F., Gorham, E.D.., Grant, W.D., Garland, F.C. (2007) Is ultraviolet $\mathrm{B}$ irradiance inversely associated with incidence rates of endometrial cancer: an ecological study of 107 countries. Prev. Med. 45: 327-331. 
Palmer, N. (1993) Bones and Joints. In Pathology of domestic animals. Jubb, KVF., Kennedy PC, and Palmer N. ed. Academic Press, Inc, Harcourt Brace Jovanovich publishers, San Diego. pp1-181.

Pan, M., Li, Z., Yeung, V., Xu, R.J. (2010) Dietary supplementationt of soy germ phytoestrogens or estradiol improves spatial memory performance and increases gene expression of BDNF, TrkB receptor and synaptic factors in ovariectomized rats. Nutrition and Metabolism. 7: 75.

Potu, B.K., Nampurath, G.K., Chamallamudi, M.R., Prasad, K., Nayak, S.R., Dharmavarapu, P.K., Kedage, V., Bath, K.M. (2009) Evidence-based assesmaent antiosteoporotic activity of petrolium ether extract of ossus quadrangularis linn : on ovariectomy-induced osteoporosis. Ups. J. Med. Sci. 114: 140-148.

Raisz, L.C. (2005) Pathogenesis osteoporosis: conceps, conflicts, and prospects. The Journal of clinical Investigations. 115: 3318-3325.

Romagnoli, E., Mascia, M.L.,Cipriani, C., Fassino, V., Mazzei, F., D’Erasmo, E., Carnevale, V., Scillitani, A. and Minisola, S. (2008) Short and long-term variations in serum calciotropic hormones after a single very large dose of ergocalciferol (vitamin D2) or cholecalciferol (vitamin D3) in the elderly. J. Clin. Endrocrinol. \& Metab. 93: 3015-3020.

Ribot, C., and Tremollieres, F. (2006) Hormone replacement therapy in the management of postmenopausal osteoporosis and prevention of fracture risk. Press. Med. 35: 1557-1563.

Riggs, B.L., Khosla, S., and Melton, L.J. (2002) Sex steroids and the construction and conservation of the adult skeleton. Endocr. Rev. 23: 279-302.

Rizzoli, R., Boonen, S., Brandi, M.L., Burlet, N., Delmas, N., and Reginster, J.Y. (2008) The role of calcium and vitamin $\mathrm{D}$ in the management of osteoporosis. Bone. 42: 246-249.
Robertone, J.L. (1998) Chemically induced glomeruler injury: A review of basic mechanisms and specific xenobiotics. Toxicologic Pathology. 26(1): 64-72.

Rodriguez, J.P., Garat, S., Gajardo, H., Pino, A.M., Seitz, G. (1999) Abnormal osteogenesis in osteoporotic patients is reflected by altered mesenchymal stem cells dynamics. J. Cell. Biochem. 75: 414-423.

Salazar-Martinez, E., Lazcano-Ponce, E., Sanchez-Zamorano, L.M., Gonzales-Lira, G., Escudero-DE Los, R.P., HernandesAvila, M. (2005) Dietary factors and endometrial cancer risk. Results of a casecontrol study in Mexico. In J. Gynecol. Cancer. 15: 938-945.

Seamans, K.M. and Cashman, K.D. (2009) Existing and potentially novel functional marker of vitamin D status : a systematic review. Am. J. clin. nutr. 89: 1997S-2008S.

Seeman, E., Vellas, B., Benhamou, C., Aquino, J.P., Semler, J., Kaufman, J.M., Hoszowski, K., Varela, A.R., Fiore, C., Brixen, K., reginster, J.Y., Boonen, S. (2006) Strontium ranelate reduce the risk of vertebral and nonvertebral fractures in women eighty years of age and older. $J$. Bone Miner. Res. 21: 1113-1120.

Selby, P.L., Davies, M., Marks, J.S., Mawer, E.B. (1995) Vitamin D intoxication causes hypercalcemia by increased bone resorption which responds topamidronate. Clin. Endocrinol. 43: 531-536.

Shiizaki, K., Hatamura, I., Negi, S., Nakazawa, E., Tozawa, R., Izawa, S., Akizawa, T., Kusano, E. (2008) Cellular changes following direct vitamin $\mathrm{D}$ injection into the uraemia-induced hyperplastic parathyroid gland. N.D.T. Plus 1 (suppl 3): iii42-iii48.

Shiraishi, A., Takeda, S., Masaki, T., Higuchi, Y., Uchiyama, Y., Kubodera, N., Sato, K., Ikeda, K., Nakamura, T., Matsumoto, T., Ogata, E. (2000)Alfacalcidol inhibits bone resorption and stimulates formation in an ovariectomized rat model of osteoporosis: 
distinct actions from estrogen. J. bone Mine.r Res. 15: 235-244.

Shuid, A.N., Ping, L.L., Muhammad, N., Soelaiman, I.N. (2011) The effects of labisia pumila var alata on bone markers and bone calcium in a rat model of post-menopausal osteoporosis. Ehnopharmacol. 133(2): 538-542.

Silva, P.T.D., Oloris, S.C.S., Avanzo, J.L., Fukumasu, H., Silva da, T.C., HernandezBlazquez, F.J., Dagli, M.L.Z. (2008) Compensatory kidney hypertrophy/ hyperplasia after nephrectomy in mice : alterations of connexin $43(\mathrm{Cx} 43)$ phosphorylated isoforms. Braz. J. Vet. Pathol. 1(1): 3-9.

Song, Y., Fleet, J.C. (2007) Intestinal resistence to 1,25 Dihydroxyvitamin $\mathrm{D}$ in Mice Heterzygous for the Vitamin D Receptor Knouckout Allele. Endocrinology. 148 (3): 1396-1402.

Song, Y., Kato, S., Fleet, J.C. (2003) Vitamin D Receptor (VDR) Knockout Mice Reveal VDR-Independent Regulation of Intestinal Calcium Absorption and $\mathrm{ECaC} 2$ and Calbindin $\mathrm{D}_{9 \mathrm{k}}$ mRNA. J. Nutr. 133: 374-380.

Sun, X., Zemel, M.B. (2004) Role of uncoupling protein 2 (UCP2) expression and 1alpha, 25-dihydroxyvitamin D3 in modulating adipocyte apoptosis. Faseb. J. 18: 14301432.

Teitelbaum, S.L., Ross, F.P. (2003) Genetic regulation of osteoclast development and function. Nat. Rev. Genet. 4: 638-649.

Teoh, S.L., Latief, A.A. (2010) Histological changes in the kidney of experimental diabetic rats fed with Momordica charantia (bitter gourd) extract. Romanian Journal of morphology and embryology. 5(1): 91-95.

Udell, J.A., Fischer, M.A., Brookhart, M.A., Solomon, D.H., Choundhry, N.K. (2006) Effect of the women's health initiative on osteoporosis therapy and expenditure in medicated. J. Bone Miner. Res. 21: 765717.
Vaananen, H.K., Zhao, H., Mulari, M., Halleen, J.M. (2000) The cell biology of osteoclast function. J. Cell. Sci. 113: 377-81.

Van Abel, M., Hoenderop, J.G., van der Kemp, A.W., van Leeuwen, J.P. Bindels, R.J. (2003) Regulation of the epithelial $\mathrm{Ca}^{2+}$ channels in small intestine as studied by quantitative mRNA detection. Am. J. Physiol. Gastrointest Liver Physiol. 285: 978-985.

Van Cromphaut, S.J., Dewerchin, M., Hoenderop, J.G., Stockmans, I., Van Herck, E., Kato, S., Bindels, R.J., Collen, D., Carmeliet, P., Bouillon, R., Carmeliet, G. (2001) Duodenal calcium absorption in vitamin $\mathrm{D}$ receptor-knockout mice: functional and molecular aspects. Proc. Natl. Acad. Sci. U.S.A. 98: 13324-13329.

Van de Graaft, S.F., Boullart, I., Hoenderop, J.G., Bindels, R.J. (2004) Regulation of the epithelial $\mathrm{Ca}^{2+}$ channels TRPV5 and TRPV6 by $1 \alpha, 25$ dihydroxy vitamin $\mathrm{D}_{3}$ and dietary $\mathrm{Ca}^{2+}$. J. Steroid Biochem. Mol. Biol. 89-90: 303-308.

Weisberg, S.P, McCann, D., Desai, M., Rosenbaum, M., Leibel, R.L., Ferrante, A.W. Jr. (2003) Obesity is associated with macrophage accumulation in adipose tissue. J. Clin. Invest. 112(12): 17851808.

Verma, S., Rajaratnam, J.H., Denton, J., Hoyland, J.A., Byers, R.J. (2002) Adipocytic proportion of bone marrow is inversely related to bone formation in osteoporosis. J. Clin. Pathol. 55: 693-698.

Vieth, R., Milojevic, S., Peltekova, V. (2000) Improved cholecalciferol nutrition in rats is noncalcemic, suppresses parathyroid hormone and increases responsiveness to 1,25 dihydroxycholecalciferol. J. Nutr. 130: 578-584.

Wood, R.J., Fleets, J.C., Cashman, K., Bruns, M.E., Deluca, H.F. (1998) Intestinal calcium Absorption in the Aged rats : Evidence of Intestinal resistence to $1,25(\mathrm{OH}) 2$ Vitamin D. Endocrinology. 39(9): 3843-3848. 
Yacobus, C.H., Holick, M.F., Shao, Q. (1992) Hypervitaminosis associated with drinking milk. N. Eng.l J. Med. 326: 1173-1177.

Yoshida, Y., Fogo, A., and Ichikawa, I. (1989) Glomeruler hemodynamic changes vs hypertrophy in experimental glomerular sclerosis. Kidney Int. 35: 654-660.

Zarate, A., Hernandez-Valencia, M., Saucedo, R., Basurto, L., Manuel-Apolinar, L., (2014) Current position about the use of estrogen therapy in women during the menopause period. Review of Medical Instruments. 52(1): 66-69.
Zhou, Y.S., Liu, Y.S., Tan, J.G. (2006) Is 1, 25-dihydroxyvitamin D3 an ideal substitute for dexamethasone for inducing osteogenic differentiation of human adipose tissue-derived stromal cells in vitro? Chin. Med. J. (Engl). 119: 12781286. 